\title{
EXTENT AND REASONS FOR MEADOWS IN SOUTH BOHEMIA BECOMING UNSUITABLE FOR ORCHIDS
}

\author{
ZUZANA ŠTÍPKOVÁ $1,2, *$ and PAVEL KINDLMANN ${ }^{1,2}$ \\ ${ }^{1}$ Global Change Research Centre, Academy of Sciences of the Czech Republic, Bělidla 986/4a, 60300 Brno, Czech Republic \\ ${ }^{2}$ Institute for Environmental Studies, Faculty of Science, Charles University, Benátská 2, 12801 Prague 2, Czech Republic \\ * Corresponding author: zaza.zuza@seznam.cz
}

\begin{abstract}
Decline in wet grasslands, which in the past resulted particularly from the intensification of agriculture, was accompanied by the loss of a lot of populations of organisms, including protected and endangered species of plants and animals associated with these habitats e.g. terrestrial orchids. The survival of populations of many species of European orchids is strongly dependent on appropriate site management especially regular mowing or grazing. In addition, humans can negatively affect the persistence of orchid populations in various ways, such as conversion of orchid meadows into building areas, dams, roads etc. or the intensive use of fertilizers and contamination of areas by fertilisers from nearby fields. Comparison of historical data with the present distribution of orchids can reveal a lot about the main reasons for the decline in this endangered group of plants. Here we present an extensive study of the persistence of 192 historical orchid sites in South Bohemia, with particular reference to the 5 commonest species of orchids, Anacamptis morio, Dactylorhiza majalis, Epipactis helleborine, Epipactis palustris and Platanthera bifolia. We show that the most abundant species at the sites studied was Dactylorhiza majalis. E. palustris, A. morio and P. bifolia are currently not present at any of the historical localities for these species. Considering more recent history, the situation regarding orchid localities in South Bohemia is not critical, but the fate of these species should be closely monitored. The majority of this loss is due to the cessation of mowing of the sites. Thus more attention should be paid to the management of the existing sites. During this study, some new sites were discovered.
\end{abstract}

Keywords: extinction, meadows, terrestrial orchids, South Bohemia

\section{Introduction}

The diversity of life on Earth is in rapid decline (Dirzo and Raven 2003; Possingham and Wilson 2005). Thus understanding the main factors determining species diversity is crucial for their survival (Possingham and Wilson 2005) and identifying important areas for their conservation (Tsiftsis et al. 2011). This is especially the case for threatened groups such as orchids (Efimov 2011; Feldman and Prat 2011).

Extensively cultivated, species-rich wet meadows have until recently been a common part of the central European landscape. These, from the viewpoint of a farmer, are frequently regarded as secondary habitats and their value is still not fully appreciated, not only from a landscape viewpoint (in particular the retention of water in the countryside with all its consequences for the local microclimate), but also because of their high and valuable contribution to the biodiversity of the area. Decline in wet grasslands, which started in the past and was particularly associated with the intensification of agriculture, was accompanied by the extinction of a lot of populations of organisms, including those of protected and endangered species of plants and animals associated with these habitats, e.g., terrestrial orchids (Wotavová et al. 2004).

The survival of populations of many European orchids is very dependent on appropriate site management, especially regular mowing or grazing (Waite and Hutchings 1991; Lind 1992; Kull 2002). Mowing is generally considered to result in conditions favourable for orchids
(Kull 2002), but present methods of mowing does not necessarily result in the persistence of orchid populations (Tamm 1991). Effect of management on orchid populations is best assessed by long-term monitoring (Inghe and Tamm 1988; Wells and Cox 1989, 1991; Vanhecke 1991; Willems and Bik 1991; Falb and Leopold 1993; Sieg and King 1995; Gill 1996; Wells et al. 1998; Kindlmann and Balounová 2001; Brzosko 2002; Janečková and Kindlmann 2002; Jersáková et al. 2002; Øien and Moen 2002; Tali 2002 etc.).

Humans, however, can negatively affect the persistence of orchid populations in many other ways. One is direct conversion of orchid meadows into building areas, dams, roads or other products of civilisation. The other is intensification of agriculture: negative side-effects of modern agricultural management (intensive use of fertilizers or contamination by fertilisers washed out from nearby fields) on the occurrence of orchid populations are confirmed by the results of several manipulative experiments (Dijk and Olff 1994; Silvertown et al. 1994; McKendrick 1996).

Comparison of historical data with the present distribution of orchids can reveal a lot about the main reasons for the decline in this endangered group of plants. This was previously done for the common orchid species Dactylorhiza majalis at 50 historical sites in South Bohemia by Wotavová et al. (2004). They found that the main reasons for its extinction were cessation of mowing, intensive use of fertilizers and contamination by fertilisers washed out from nearby fields. 
Here we present a much more extensive study of the persistence of 192 historical orchid sites in South Bohemia, with particular reference to the 5 commonest orchid species, Dactylorhiza majalis, Epipactis helleborine, Epipactis palustris, Anacamptis morio and Platanthera bifolia. Four of them live in meadows and E. helleborine is a forest species, which is included for comparison. Our results indicate that the most abundant species at the sites studied is Dactylorhiza majalis. No plants of E. palustris, A. morio and P. bifolia were found at any of the historical localities. Considering the more recent history, the situation regarding orchid localities in South Bohemia is not critical, but these species should be closely monitored. The majority of the extinctions were recorded at sites that are no longer mowed, which is consistent with the results of Wotavová et al. (2004). Thus more attention should be paid to the management of existing sites. During this study, some new sites were discovered.

\section{Methods}

For our analyses, we selected the following five most abundant species in the study area:

- Dactylorhiza majalis, also known as the western-marsh orchid (Reichenb., Hunt and Summerh), has a relatively wide ecological tolerance occurring in lowlands and mountains, in wet to damp meadows, wetlands and peatlands and is less sensitive to high levels of nitrogen than other orchid species (Jatiová and Šmiták 1996; Wotavová et al. 2004; Janečková et al. 2006). Its leaves appear usually during April and last until July and it flowers mainly in May and June (Wotavová et al. 2004; Janečková et al. 2006). This species is almost extinct in lowland basins, where it survives mainly in protected areas (Jatiová and Šmiták 1996). Generally speaking, it is classified among the most vulnerable species by the IUCN (Wotavová et al. 2004).

- Broad-leaved helleborine (Epipactis helleborine (L.) Crantz) is the commonest and most widely distributed species in this genus and occurs from the Mediterranean area to boreal zones up to $2000 \mathrm{~m}$ (Ehlers et al. 2002; Delforge 2006). It grows in forests, at forest edges and also in anthropogenic habitats such as rural and urban road verges, tracks, parks and lawns (Hollingsworth and Dickson 1997; Stefaniak et al. 2011) and flowers mainly from June to September (Rewicz et al. 2015). In this study, it is the only representative of a forest species.

- Epipactis palustris (marsh helleborine) is widely distributed occurring throughout most of Europe, but totally absent from the southern Mediterranean region. This species grows on moist to wet substrates, which are poor in nutrients. It has a long flowering period; however, the peak of flowering occurs between mid-July and mid-August (Jacquemyn et al. 2014).
- Anacamptis morio is a perennial herb, which has a broad ecological range and occurs in various habitats: in semi-wet meadows, pastures and on shrubby slopes in lowland areas and the submontane zone (Delforge 1995; Jersáková et al. 2002). This species flowers in early May and after seed dissemination all above ground parts die off and the first leaves appear again in September to October. A. morio belongs to the orchid group with an above ground rosette, which persists over winter (Jersáková et al. 2002).

- Platanthera bifolia (bog orchid), is found in moist habitats in temperate and subtropical regions (Patt et al. 1989). It is a terrestrial orchid with a Eurasian distribution (Hultén and Fries 1986), growing in open forests and meadows (Stpiczyńska 1997) and flowering from May to July (www.botany.cz).

We surveyed all the available historical and recent databases of terrestrial orchid localities in South Bohemia. We selected at random a total of 192 of these orchid localities, which according to the databases hosted some of the above five species in the past and revisited all of them in the flowering periods of the orchid species indicated as present there in the databases. We distinguished "historical sites", those reported before 2000, and "recent sites", those reported after 2000. The choice of the year 2000 as a border line between "historical" and "recent" sites was chosen arbitrarily.

At each of the sites where there were no longer any orchids we determined the reason for this as either "overgrown", lack of mowing or grazing, or "human pressure", conversion of orchid meadows into building areas like dams, roads or other products of civilisation, or effects of intensive use of fertilizers or contamination by fertilizers washed out from nearby fields. Some sites were labelled as "not found" or "undiscovered". This was the cases when a site corresponding to the description in the database was not found in the area indicated or in the vicinity of up to about $1 \mathrm{~km}$. These may be cases where man has changed the landscape so dramatically during recent decades (e.g., by merging fields, building roads or other buildings) that the original site was no longer recognizable.

\section{Results}

During 2014 we visited a total of 192 localities. Numbers of localities visited where the five most abundant species were recorded are shown in Table 1. Fig. 1 presents numbers of sites where there were living orchids, where there were currently no orchids and those that could not be found. The most abundant species was D. majalis, most likely because it is less demanding in terms of environmental conditions than the other species.

The commonest causes of localities becoming unsuitable for orchids are given in Fig. 2: overgrowing of the 
site by other more dominant species. Even some forest sites of E. helleborine were overgrown by undergrowth. Other causes include human activities like converting meadows into fields or deforestation in the case of $E$. helleborine.

Figs. 3 and 4 show the effect of differences in management on populations of E. palustris and A. morio. Both of the sites for A. morio hosted a viable population of this species 15 years ago. The population at the unmown site went extinct, while that at the mown site is thriving and consists of tens of thousands of flowering plants.

Figs. 5 and 6 show the percentage of localities that became unsuitable for particular orchids (Fig. 5) and at historical vs. recently recorded localities (Fig. 6). There were no records of historical localities in the databases for this species, which explains the lack of corresponding data in Fig. 6.

For orchid dynamics it is very important that even during the first year we found a number of previously unrecorded localities (Fig. 7): 11 for D. majalis, 12 for E. helleborine and 1 each for O. morio and P. bifolia. No new localities were recorded for $E$. palustris.

\section{Discussion}

The small decline in the number of localities with D. majalis may be due to its typical habitat, wet meadows, being unsuitable for farming and therefore its localities were usually not as much affected by people as other kinds of habitats. The decline in this species was therefore caused mainly by the absence of mowing and intensive use fertilizer (Wotavová et al. 2004). Jatiová and Šmiták (1996) in contrast, report that only 202 out of 1141 sites for D. majalis in Moravia (eastern part of the Czech Republic) still hosted this species in 1995. It may be that agricultural intensification was more marked in Moravia. It is a general trend that wet meadows, which are rich in biodiversity, are currently rapidly disappearing (Wotavová et al. 2004).

E. helleborine is a forest species. Forests have not been disturbed as much as open localities and therefore there has been less of a decline in the number of suitable localities for E. helleborine. According to Rewicz et al. (2015), there are big differences between natural and anthropogenic populations of $E$. hellebrine in the amount of seed

Table 1 Number of localities with the five most abundant species visited in South Bohemia.

\begin{tabular}{|l|c|}
\hline Species & Number of localities visited \\
\hline Dactylorhiza majalis & 121 \\
\hline Epipactis helleborine & 28 \\
\hline Epipactis palustris & 6 \\
\hline Anacamptis morio & 12 \\
\hline Platanthera bifolia & 25 \\
\hline
\end{tabular}

produced and the size of the plants, which can affect its population dynamics and therefore its persistence in the countryside.

E. palustris has similar ecological demands to D. majalis, so the decline in the number of suitable localities for this species is similar, except for historical sites. However, the databases contain only 2 historical sites, neither of which are now suitable and therefore this estimate is not

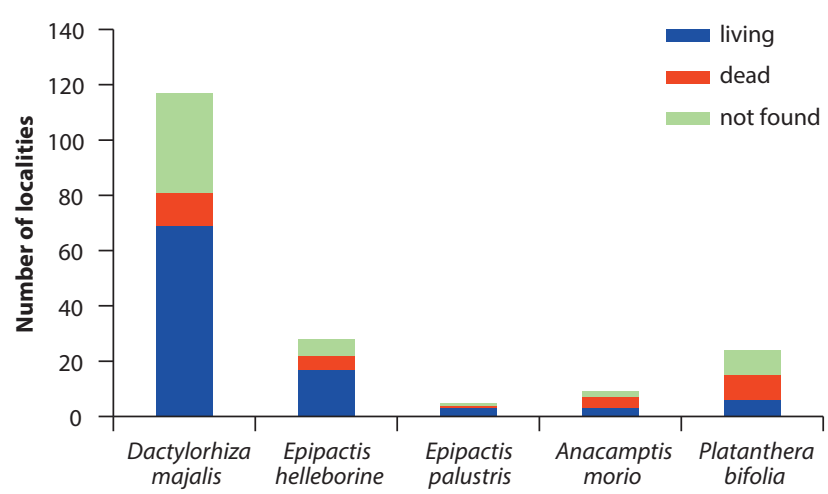

Fig. 1 Number of localities in South Bohemia where the different orchids are currently present or extinct, and the number of localities that could not be found.

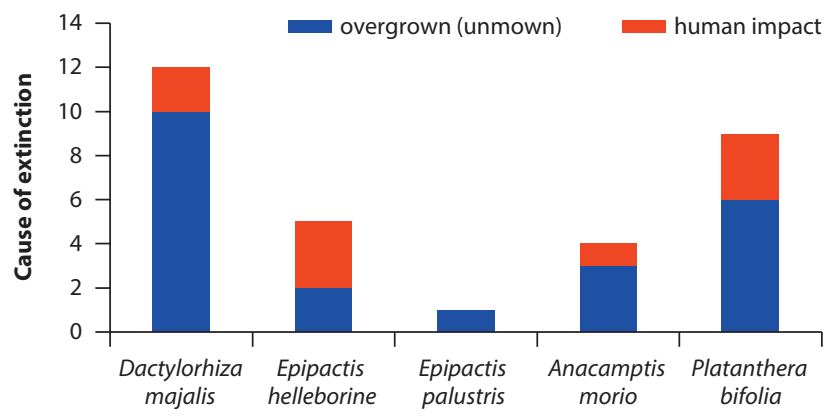

Fig. 2 Main causes of localities becoming unsuitable for orchids in South Bohemia.

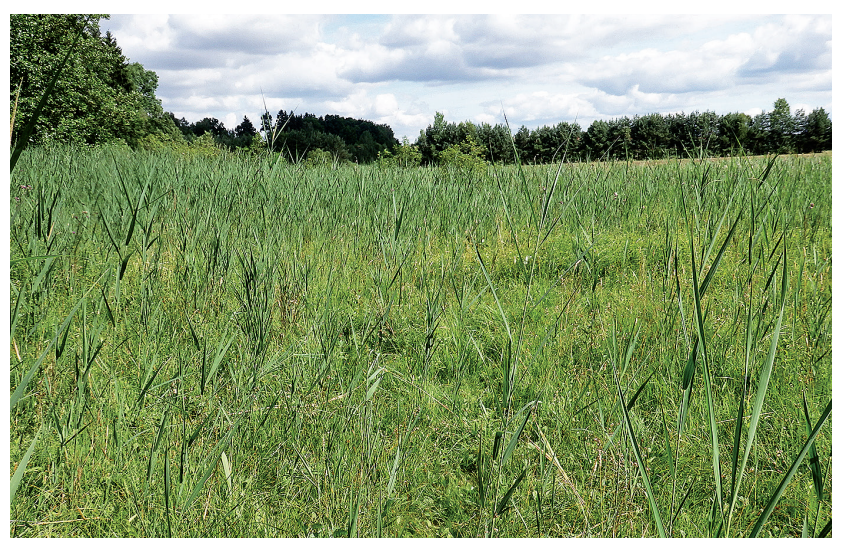

Fig. 3 Photograph showing the overgrowing of a locality for Epipactis palustris by Phragmites australis. 

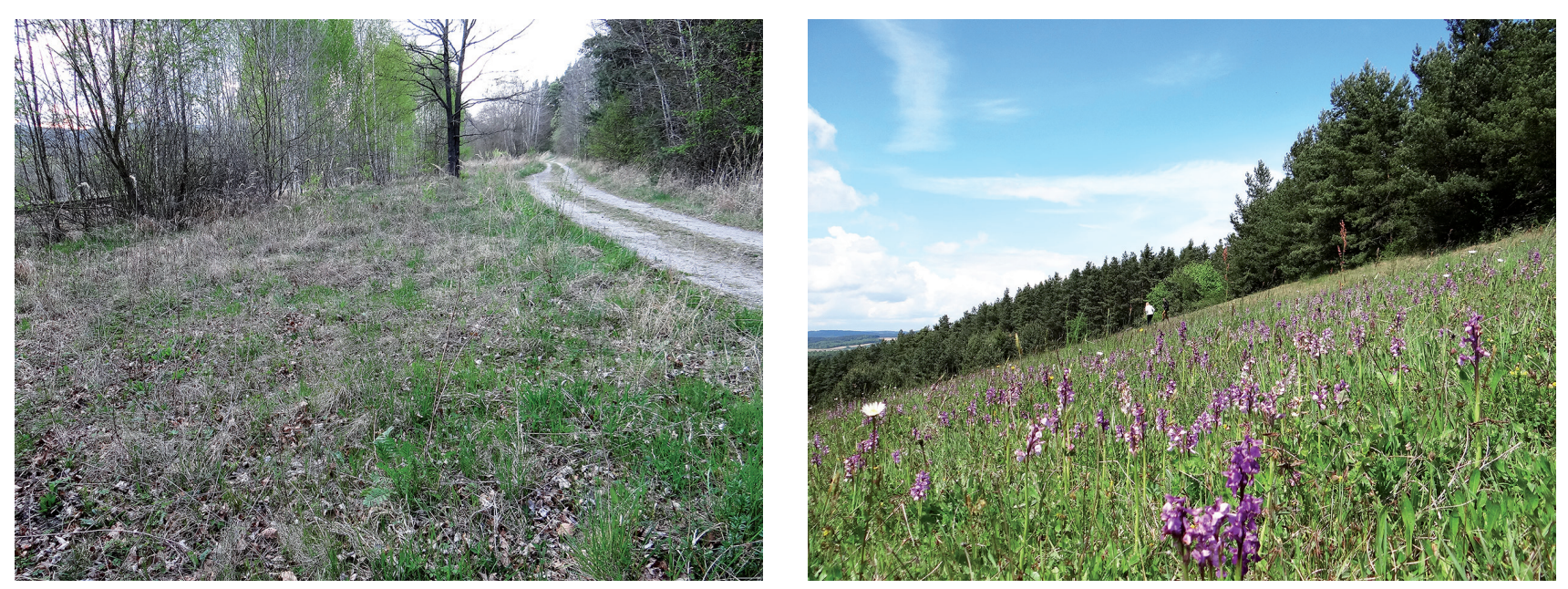

Fig. 4 Comparison of an unmown (A) and mown (B) site for A. morio. Both sites hosted a viable population of this species 15 years ago. The population at the unmown site went extinct, while that at the mown site is thriving and hosts ten of thousands of flowering plants.

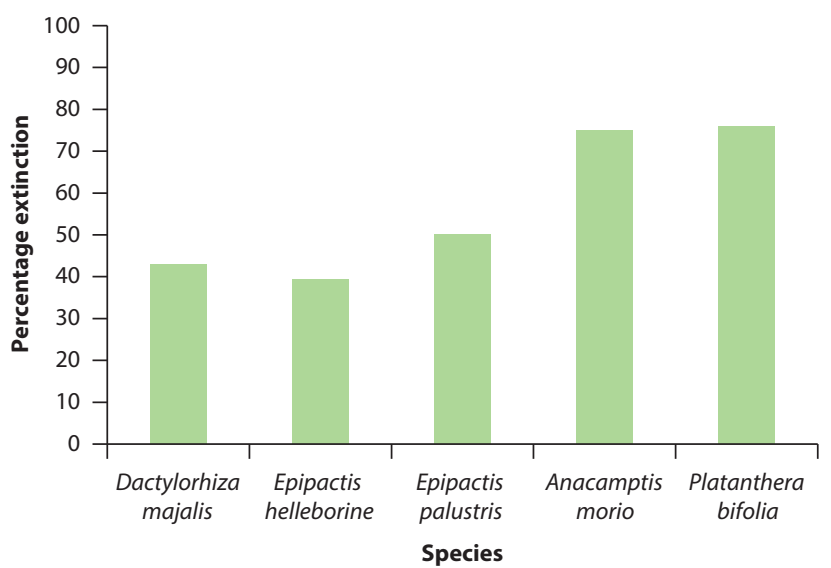

Fig. 5 Percentage extinctions at all localities for the five species of orchids.

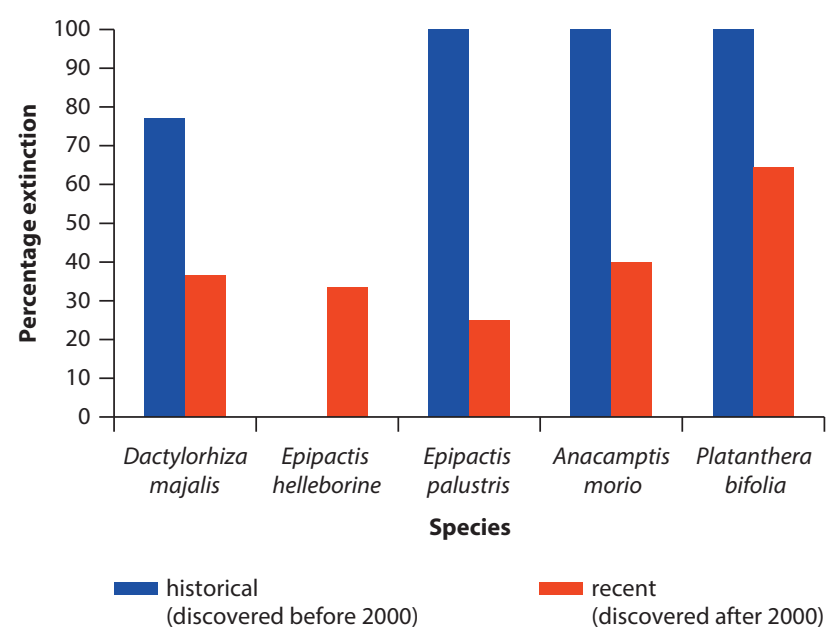

Fig. 6 Percentage extinctions at historical vs. recent localities for the five species of orchids.

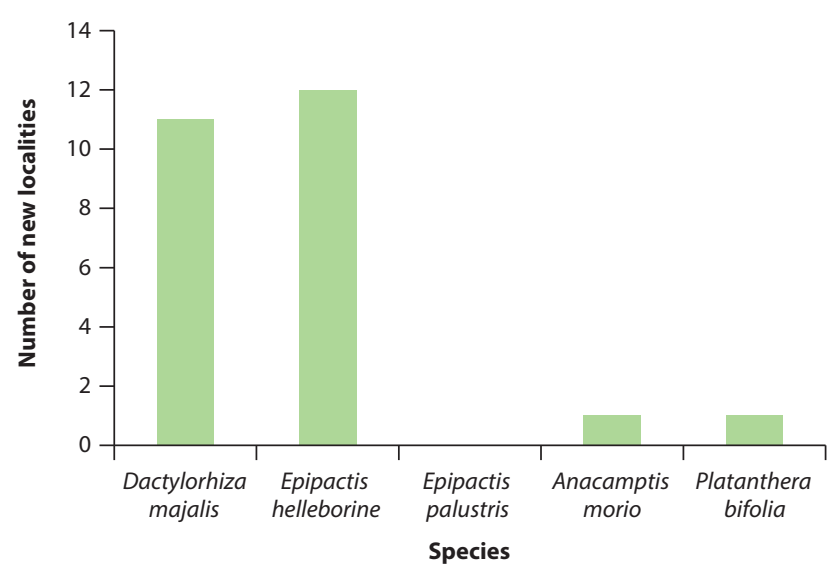

Fig. 7 Number of new localities recorded during summer 2014.

reliable. In fact, there has been a marked decline in the distribution of E. palustris in Britain (Kull and Hutchings 2006). The number of populations declined by about $24.6 \%$, most of which disappeared before 1930 . The major cause of its decline is believed to be drainage of marshes together with agricultural improvements and inadequate management (Jacquemyn et al. 2014).

A. morio grows in dry meadows and pastures in the study area, which were very often converted into agricultural fields and because of this the number of localities for this species declined (especially in the case of the historical localities). Another reason for the rapid decline might be the cessation of mowing or management in general (Fig. 4; see also Kindlmann and Balounová 1999, 2000; Jersáková et al. 2002).

The situation for P. bifolia is more complicated. This species seems to be affected by habitat conditions, as they differ in size, proportion of flowering individuals and the effectiveness of reproduction, which is connect- 
ed with their ability to store resources before flowering (Calvo 1990; Brzosko 2003). Shade can also play a role. For example, Brzosko (2003) found that plants growing in full light had longer inflorescence and produced more flowers and fruits than those growing in shade. We are not quite sure, why the decline was so dramatic in the populations studied. More research is therefore needed on this topic.

\section{Conclusions}

Our results indicate that the most abundant species at the sites studied was Dactylorhiza majalis. There are currently no plants of E. palustris, A. morio and P. bifolia at any of the historical localities for these species. Considering more recent history, the situation regarding orchid localities in South Bohemia is not critical, but these species should be closely monitored. The majority of extinctions was due to cessation of mowing, which is consistent with the results of Wotavová et al. (2004). Thus more attention should be paid to the management of existing sites. During this study, some new localities for these orchids were recorded.

\section{Acknowledgements}

This work was supported by the grant No. 14-36098G of the GA CR.

\section{REFERENCES}

Brzosko E (2002) Dynamics of island populations of Cypripedium calceolus in the Biebrza river valley (north-east Poland). Bot J Linn Soc 139: 67-77.

Brzosko E (2003) The dynamics of islands populations of Platanthera bifolia in the Biebrza National Park (NE Poland). Ann Bot Fenn 40: 243-253.

Calvo RN (1990) Four-year growth and reproduction of Cyclopogon cranichoides (Orchidaceae) in South Florida. Am J Bot 77: 736-741.

Delforge P (2006) Orchids of Europe, North Africa and the Middle East. AC Black Publishers, London, UK.

Delforge P (1995) Orchids of Britain and Europe. Harper and Collins, London, UK.

Dijk E, Olff H (1994) Effects of nitrogen, phosphate and potassium fertilization on field performance of Dactylorhiza majalis (Rchb.) Hunt and Summerh. Acta Bot Neerl 43: 383-392.

Dirzo R, Raven PH (2003) Global state of biodiversity and loss. Ann Rev Environ Res 28: 137-167.

Efimov PG (2011): Revealing the decline and expansion of orchids of NW European Russia. Eur J Environ Sci 1: 7-17.

Ehlers BK, Olesen JM, Gren JA (2002) Floral morphology and reproductive success in the orchid Epipactis helleborine: regional and local across-habitat variation. Plant Syst Evol 236: 19-32.

Falb DL, Leopold DJ (1993) Population dynamics of Cypripedium candidum muhl. Ex willd., small white ladyslipper, in aWestern New York fen. Nat Areas J 13: 76-86.
Feldman P, Prat D (2011) Conservation recommendations from a large survey of French orchids. Eur J Environ Sci 1: 18-27.

Gill DE (1996) The natural population ecology of temperate terrestrials: pink lady's slippers, Cypripedium acaule. In: Allen C (ed) Proceedings of the North American native terrestrial orchids: propagation and production, north american native terrestrial orchid conference, Germantown, MD, pp. 91-106.

Hollingsworth PM, Dickson JH (1997) Genetic variation in rural and urban populations of Epicpatis helleborine (Orchidaceae) in Britain. Bot J Linn Soc 123: 321-331.

Hultén E, Fries M (1986) Atlas of North European vascular plants: north of the Tropic of Cancer. Koeltz Scientific Books, Königstein, Germany.

Inghe O, Tamm CO (1988) Survival and flowering of perennial herbs. V. Patterns of flowering. Oikos 51: 203-219.

Jacquemyn H, Brys R, Hutchings MJ (2014) Biological Flora of the British Isles: Epipactis palustris. J Ecol 102: 1341-1355.

Janečková P, Kindlmann P (2002) Key factors affecting shoot growth and flowering performance of Dactylorhiza fuchsii. In: Kindlmann P, Willems JH, Whugham DF (eds) Trends and fluctuations and underlying mechanisms in terrestrial orchid populations. Backhuys Publishers, Leiden, pp. 99-113.

Janečková P, Wotavová K, Schödelbauerová I, Jersáková J, Kindlmann P (2006) Relative effects of management and environmental conditions on performance and survival of population of a terrestrial orchid, Dactylorhiza majalis. Biol Conserv 129: 40-49.

Jatiová M, Šmiták J (1996) Rozšíření a ochrana orchidejí na Moravě a Slezsku (Distribution and protection of orchids in Moravia and Silesia). Agentura ochrany př́rody a krajiny, Brno.

Jersáková J, Kindlmann P, Stř́iteský M (2002) Population dynamics of Orchis morio in the Czech Republic under human influence. In: Kindlmann P, Willems JH, Whigham DF (eds) Trends and fluctuations and underlying mechanisms in terrestrial orchid populations. Backhuys Publishers, Leiden, pp. 209-224.

Kindlmann P, Balounová Z (1999) Flowering regimes of terrestrial orchids: chaos or regularity? J Veg Sci 10: 269-273.

Kindlmann P, Balounová Z (2001) Irregular flowering patterns in terrestrial orchids: theories vs. empirical data. Web Ecology 2: $75-82$.

Kull T (2002) Population dynamics of north temperate orchids. In: Kull T, Arditti J (eds) Orchid biology: Reviews and perspectives, VIII. Kluwer Academic Publishers, Dordrecht, pp. 139-165.

Kull T, Hutchings MJ (2006) A comparative analyses of decline in the distribution ranges of orchid species in Estonia and the United Kingdom. Biol Conserv 129: 31-39.

Lind H (1992) Förekomst,beståndsutveckling och fruktsättning hos salepsrot pä Öland. Svensk Botaniska Tidskrift 86: 329-336.

McKendrick SL (1996) The effects of shade on seedlings of Orchis morio and Dactylorhiza fuchsii in chalk and clay soil. New Phytol 134: 343-352.

Øien DI, Moen A (2002) Flowering and survival of Dactylorhiza lapponica and Gymnadenia conopsea in the Sølendet Nature Reserve, Central Norway. In: Kindlmann P, Willems JH, Whigham DF (eds) Trends and fluctuations and underlying mechanisms in terrestrial orchid populations. Backhuys Publishers, Leiden, pp. 3-22.

Patt JM, Merchant MW, Williams DRE, Meeuse BJD (1989) Pollination biology of Platanthera stricta (Orchidaceae) in Olympic Park, Washington. Am J Bot 76: 1097-1106.

Possingham HP, Wilson KA (2005) Turning up the heat on hotspots. Nature 436: 919-920.

Rewicz A, Kołodziejek J, Jakubska-Busse A (2015) The role of anthropogenic habitats as substitues fot natural habitats: a case 
study on Epipactis helleborine (L.) Crantz (Orchidaceae, Neottieae). Variations in size and nutrient composition of seeds. Turk J Bot 39: 1-11.

Sieg CH, King RM (1995) Influence of environmental factors and preliminary demographic analyses of a threatened orchid, Platanthera praeclara. Am Midl Nat 134: 307-323.

Silvertown J, Wells DA, Gillman M, Dodd ME, Robertson H, Lakhani KH (1994) Short-term effects and long-term after-effetcs of fertilizer application on the flowering population of green-winged orchid Orchis morio. Biol Conserv 69: 191-197.

Stefaniak A, Adamowski W, Święczkowska E, Jakubska-Busse A (2011) Changes in the abundance and population density of Epipactis helleborine (L.) Crantz (Orchidaceae) in anthropogenic habitats in northeastern Poland. Acta Bot Silesiana 7: 189-196.

Stpiczyńska M (1997) The structure of nectary of Platanthera bifolia L. Orchidaceae. Acta Soc Bot Pol 66: 5-11.

Tali K (2002) Dynamics of Orchis ustulata populations in Estonia. In: Kindlmann P, Willems JH, Whigham DF (eds) Trends and fluctuations and underlying mechanisms in terrestrial orchid populations. Backhuys Publishers, Leiden, pp. 33-42.

Tamm CO (1991) Population ecology of terrestrial orchids. In: Wells TC, Willems JH (eds) SPB Academic Publishing, The Hague, pp. 1-13.

Tsiftsis S, Tsiripidis I, Trigas R (2011) Identifying important areas for orchid conservation in Crete. Eur J Environ Sci 1: 28-37.

Vanhecke L (1991) Population dynamics of Dactylorhiza praetermissa in relation to topography and inundation. In: Wells TC,
Willems JH (eds) Population ecology of terrestrial orchids. SPB Academic Publishing, The Hague, pp. 15-32.

Waite S, Hutchings MJ (1991) The effects of different management regimes pn the population dynamics of Ophrys sphegodes: analysis and description using matrix models. In: Wells TC, Willems JH (eds) Population ecology of terrestrial orchids. SPB Academic Publishing, The Hague, pp. 161-175.

Wells TCE, Cox R (1989) Predicting the probability of the bee orchid (Ophrys apifera) flowering or remaining vegetative from the size and number of leaves. In: Pritchard HW (ed) Modern methods in orchid conservation: the role of physiology, ecology, and management. Cambridge University Press, Cambridge, pp. $127-139$.

Wells TCE, Cox R (1991) Demographic and biological studies of Ophrys apifera: some results from a 10 year study. In: Wells TC, Willems JH (eds) Population ecology of terrestrial orchids. SPB Academic Publishing, The Hague, pp. 47-61.

Wells TCE, Rothery P, Cox R, Bamford S (1998) Flowering dynamics of Orchis morio L. and Herminium monorchis (L.) R. Br. at two sites in eastern England. Bot J Linn Soc 126: 39-48.

Willems JH, Bik L (1991) Long-term dynamics in a population of Orchis simia in the Netherlands. In: Wells TC, Willems JH (eds) Population ecology of terrestrial orchids. SPB Academic Publishing, The Hague, pp. 33-45.

Wotavová K, Balounová Z, Kindlmann P (2004) Factors affecting persistence of terrestrial orchids in wet meadows and implications for their conservation in a changing agricultural landscape. Biol Conserv 118: 271-279. 